FITRAH Jurnal Kajian Ilmu-ilmu Keislaman

Vol. 05 No. 2 Desember 2019

e-ISSN : 2460-2345, p-ISSN: 2442-6997

Web: jurnal.iain-padangsidimpuan.ac.id/index.php/F

\title{
THE LEGAL ACCOUNTABILITY TRANSPORTATION TO THE PASSENGERS AND GOODS TRANSPORT THAT CAUSED BY FORGETFULNESS
}

PUTRA HALOMOAN HSB

IAIN Padangsidimpuan

E-mail: putrahsb.halomoan@gmail.com

DOI: $h$ ttp://dx.doi.org/10.24952/fitrah.v5i2.2092

$$
\begin{aligned}
& \text { ملحص } \\
& \text { مسؤلية الحكم النقلى على الراكب والموادها وتبديل خاسربن من الإهتمال في الركاب. تبحث هذه } \\
& \text { الكتابة عن الركاب تشتمل على تعريفات الركاب ، فرد ومفرود الركاب , أنواعها وصفاعما واهدافها }
\end{aligned}
$$

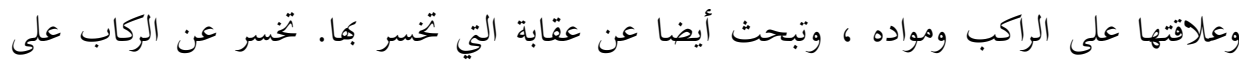

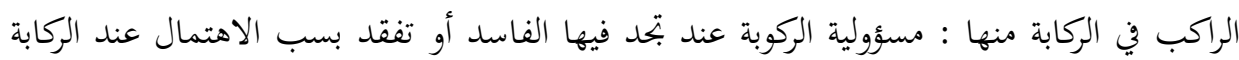

$$
\begin{aligned}
& \text { والتحديدات المسؤوليات في الركابة ـ هناك عدة مسؤولية في الركابة للراكب وهي ومسؤولية من جهة }
\end{aligned}
$$

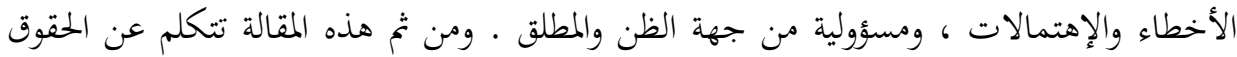

$$
\begin{aligned}
& \text { والواجبات من الراكب ومركوبما. } \\
& \text { الكلمات المفتاحية: مسؤولية الحكم ، مركوبة الراكب ، والإهتمال . }
\end{aligned}
$$

\begin{abstract}
Abstrak
Pertanggungjawaban Hukum Pengangkutan Terhadap Penumpang Dan Barang Angkutan Serta Ganti Kerugian Disebabkan Kelalaian : Artikel ini membahas tentang ruang lingkup pengangkutan termasuk definisi pengangkutan, objek dan pihak pengangkutan, jenis-jenis pengangkutan sifat dan tujuan pengangkutan serta kaitannya dengan penumpang dan barang angkutan, serta membahas tentang sanksi kerugian. Serta pertanggungjawaban pengangkutan ketika terjadi kerusakan serta kehilangan barang penumpang yang disebabkan kelalaian pihak pengangkut, dan batasan batasan yang termasuk dalam tanggungjawab pengangkutan. Dimana terdapat beberapa jenis-jenis pertanggungjawaban yang dilakukan oleh pihak pengangkut yakni pertanggungjawaban pengangkutan dilihat dari kesalahan dan kelalaian, pertanggungjawaban karena praduga dan pertanggungjawaban mutlak. Selanjutnya berbicara tentang hak dan kewajiban para pihak.
\end{abstract}

Kata Kunci: Pertanggungjawaban Hukum, Pengangkutan Penumpang, Kelalaian. 
FITRAH Jurnal Kajian Ilmu-ilmu Keislaman

Vol. 05 No. 2 Desember 2019

\section{INTRODUCTION}

Transportation is a services to transfer of goods or people from one place to another place by using land, sea and from the air transportation. In transporting the goods, the transportation can be defined which is moving goods the production and goods trade to the place of consumers and producers on the other hand for the transportation of goods for transporting goods made it possible for them obtain materials they need to producing goods .

There is no statement on the defenition put in charge of carrying in general a legal statute in the book trade ( kuhd ), that is only on the sea that is expressed in article 466 kuhd it has been said that:

"The transportation in this chapter is whoever good with the carter according to time or according to travel, either by other arrangements fastens seeks to implement for transporting goods wholly or partly through the sea."1

Then the article 521 kuhd said:" Carriers in the meaning of this chapter is whoever either by carter according to time or carter according to transit either with another agreement man joins himself to make the country transportation of people ( passengers ) wholly or partly through the ocean." ${ }^{2}$

From both defenition was mentioned by these as mentioned in article of 466 kuhd is close they can are defined in general that put in charge of carrying is: whoever which exercise a public offering for anyone to began to implement put in charge of carrying so that he is under obligation and meet a demand or not opposed to to bear and take away

Whoever in this provision can be a private person or a legal entity of laws put himself in the transportation.According to Sution Usma Adji transport is "A reciprocal agreement, which the carrier fastens themselves to implement the transportation of goods or people from the place a particular purpose, while the other side (sender or receiver ) should be pay a fee to the transportation." ${ }^{3}$

While according to Purwosutjipto Transportation is: Reciprocal agreement between for transporting with shipping, where carrying fastens to implement the

\footnotetext{
1 R. Subekti, dkk, Kitab Undang-Undang hukum Dagang, PT Pradnya Paramita,Jakarta,Cetakan 27,2002, p. 134

${ }^{2}$ R. Subekti, dkk, Kitab Undang-Undang hukum Dagang, p. 134

3 Sutiono UsmanAdji, dkk, "Hukum Pengangkutan Di Indonesia",Penerbit Rineka Citra, Bandung,1990, p. 6
} 
transportation of goods or person from a place to another place with the safely particular purpose, while the sender fastens to them to pay money transport. ${ }^{4}$

Before transporting carried out in general is an agreement between the carriers with the sender goods. In this case the agreement of transportation is the covenant of land transportation which used the bus like the agreement. It means to validity of the an agreement shall meeting requirements set in article 1320 kuhperdata and article 1338 kuhperdata about that agreement.

According to 1320 kuhperdata article the legitimacy of an agreement is:

1. The agreement those who put themselves

2. Skill to make an agreement

3. A particular thing

4. One for the good things

Then 1388 kuhperdata article said :

1. All the agreements legally valid as the act of for those who make it

2. The agreement can be drawn back besides from took counsel and plotted together both sides.

3. Agreements must be carried out with an essentially and perfectly good morally .

The ones who made a covenant here is the party for transporting with delivery of goods .So, it can be said that the agreements the transportation of basically equivalent a treaty in generally. The transportation Agreement do before doing hauling and the agreement that done in the form of agreement transportation generally is not fixed or called with the provision of intervals. ${ }^{5}$

To organize transportation, first there was an agreement between the pickup and the sender, Agreement transportation is an agreement where for transporting fastens themselves to hold transportation passengers or goods from a place to place a particular purpose safely and the sender fastens himself to pay the cost of transportation. ${ }^{6}$ The transportation always used orally still supported by documents proving that the transport agreement has happened.

In agreement transportation on put in charge of carrying holding a match point the parties the sender and carrying level namely unlike in agreement labor

4 H.M.N Purwosutjipto,Pengertian Pokok Hukum Dagang Indonesia,Jilid 3, Hukum Pengangkutan, Penerbit Djambatan, Jakarta, 1981, p. 2

${ }^{5}$ Mr. R. Soekardono, Hukum Dagang Indonesia Penerbit Soeroeng, Jakarta,1961,p. 10

6 Abdul Kadir Muhammad, Hukum pengangkutan Niaga, Penerbit PT Citra Aditya, Bandung, 1998, p. 35 
FITRAH Jurnal Kajian Ilmu-ilmu Keislaman

Vol. 05 No. 2 Desember 2019

where the parties not level, the employer enjoyed higher than workers. The parties in the labor is called a subordination ( gesubordineerd ), and the parties in the agreement on the transportation of is the same high or notch gecoordineerd ) coordinating.

The transportation, implement the agreement a working relationship between sender and the carrier did not have to constantly, but only sometimes, if the sender needs transporting to send goods. The kind of this relationship called "regular service" because the service is not, are permanent just sometimes just, if the sender need transporting, a deal this update stipulated in article 1601 kuhperdata.

In laws Constitution be determined that put in charge of carrying just been held after a charge the public transportation service paid more entitled to inherit from. But apart from the provisions in laws Constitution also applies the habit of society that would pay the cost, transport then the agreement includes activities transportation usually carriers in the broadest sense of loading, activities carry and bring down or unloading. Put in charge of carrying in the broadest sense this is closely linked to the responsibility of the carrier on when what is to happen event that give rise to kerugian.artinya the responsibility of the carrier on begins to walk a goose since passengers or goods be loaded into the transporter equipments goods to be undermined and broken corporate secretary ronald nangoi said of a tool for transporting or was delivered to the recipients.

Responsibility can be seen from an obligation that has been set in agreement or laws Constitution. Transportation is implementing the transportation of an obligation. When the passengers had an accident while riding in a carrier for transported, or while descending from a carrier, and the tranportation company have to responsible pay the all losses that arising from an accident that had occurred. ${ }^{7}$

But responsibility for transporting is bounded by laws Constitution.In laws Constitution determined that carrying are responsible over all loss resulting from a mistake, except :

1. force majeur

2. Defective goods itself

3. Error and omission the sender or proprietor of goods

\footnotetext{
${ }^{7}$ Abdul Kadir Muhammad, Hukum pengangkutan Niaga..., p. 35
} 
According to R. Soekardono, that the Agreement transportation is a reciprocal agreement, which the carrier fastens themselves to make transportation to where certain, other parties ( sender ) obligated to pay a fee to transport. ${ }^{8}$

While according to Purwostjipto that the Agreement transportation is The reciprocal agreement between the carrier fastens with shipper. when themselves to implement the transportation of goods or from place to place a particular purpose safely, while the shipper told myself to pay the transportation fee." ${ }^{\prime 9}$

Then there are the group that stated the agreement transportation is an agreement to do the work. ${ }^{10}$ Purwosutjipto the agreement transportation is a mix agreement because had instances of :

1. The Regular service ( article 1601 kuhperdata ) contractor is an agreement by which the other party, the contractor tying myself up to institute an employment for the other party, the party that putting out to contract, by accepting a specified price

2. The element of storage, a requirement in article 468 verse 1 kuhd saying The agreement of transportation of obliging the group the transporters to keep the safety of goods carried, from now until received when delivered up the goods.

3. The element of empowerment, that we can see in article 371 paragraph 1 kuhd saying Skippers are along the way of keeping, owners charge take measures to is facing the judge.

Then in paragraph 3 says; In the state of being urgent he does sell goods a charge or some of that or in order to finance expenses of its members it has extended to the interests of a charge, borrow money at the risk of the charge as security." 11

And then the transportation of activities in defiance of both sides, there is a problem many field related to the transportation of agreement that have been undertaken, good against transport of passengers and goods. Even though the purpose of the agreement to safeguarding safety goods and passengers, but there

${ }^{8}$ Mr. R. Soekardono, Hukum Dagang Indonesia, p. 10

${ }^{9}$ H.M.N Purwosutjipto,Pengertian Pokok Hukum...., p.13

10 Achmad Ichsan, Hukum Dagang Lembaga Surat-Surat Barharga, Pengangkutan", Pradnya Paramita,jakarta, 1981, p. 409

${ }^{11}$ H.M.N Purwosutjipto,Pengertian Pokok Hukum..., p. 9 
FITRAH Jurnal Kajian Ilmu-ilmu Keislaman

Vol. 05 No. 2 Desember 2019

is a possibility the risk of a constraints in trips like: accident, delay, natural disasters and forth.

In this journal will talk about the problems that which is lifted related to how the responsibility of carrying passengers and goods transport caused forgetfulness.

\section{METHOD}

Relating to the research how responsibility for transporting to transport passengers and goods. Conducted the research to find primary and secondary data with obtained by Library Research. Library Research is Study and analyzed in systematic of books, legislation, the note college and other sources dealing with matter discussed in this research.

\section{THE RESULT AND DISCUSSION}

Transportation means making it easier to a person or goods at a given place and in various ways and with different embarked on the trip. Via land, sea and the air. Where the transport was working to move goods or people from one place to another in order to increase the to and the value of the goods. ${ }^{12}$

Reciprocal agreement for transporting with the sender, where a carrier for the implementation of the transportation of goods or people of a place to place a particular purpose in peace, while the sender a transport to pay money.

To carrying out the transport of this to be in accordance with the goal, before carried out those transports must be held covenant between parties with the sender goods transport. In implementing agreement transporting there must be an object of transporting itself whereby objects transporting are :

1. Transporting goods

In transporting the goods as the object of transportation is "goods". The goods meant here are the legal and protected products by the laws Constitution. In the transport of ruminant with types of the bus charges can be transported in :

a. clothing goods as clothes and garment

b. Food items such as rice, sugar and fruits

c. Furniture as cupboard and kitchenware

12 Sutiono Usman Adji, dkk, Hukum Pengangkutan...,p. 9 
In the operating of the transportation in a one place to the other place. Both sides have an obligation they are :

a. The carrier has an obligation to transport goods or people from one to another place safely

b. The sender liable to pay an agreed fee and gave the goods are handed to recipients who was the addresses in a letter

When the transportation agreement of goods held the carriage making a deed named with the charge. Where in a letter a charge load rights as follows :

a. The name of goods, the number of heavy size of the number of the cost in a piece and in a kilogram.

b. The receivers to whom goods will be given

c. The amount of wages for transporting, signature of the sender and the transportation to be noted in the register

d. A charge but that is an agreement between carrying and sender, but a letter of charge was not binding carrying and the signature by the carrying and sender goods.

2. Individual Transportation

It is Different from the transportation of goods, because the objects in this agreement transportation is people. In this agreement, there is no submission to carrying. The carrying only transporting people to the people destination safely, and about the people goods it will carried by the passengers that including in goods transport but classified into luggage. Like a bag one is girded and a bundle in a small scale.

On transportation of people arranged in uulajr who it was stated that the transportation of people with motor vehicle obliged to use for passengers, motor vehicle in the trunk or without bagasi. And the decision is intended to ensure the safety of for the passengers.

In order to guaranteed transport services, uniformity and regularity in provision of services, determined the service of the urban area which is based on the nature and provisions, trip the distance and travel time developing an area or an area into a residential area, trade the industry offices and so on.

Understanding of the routes are still regular transport services have done in route network regularly and regular, with a permanent fixture or not 
FITRAH Jurnal Kajian Ilmu-ilmu Keislaman

Vol. 05 No. 2 Desember 2019

scheduled, While understanding it is not fixed in public transport services performed by not tied up in a certain route to the timetable in irregular transportation. ${ }^{13}$

This regulation was intended to control the vehicle with public transport services in order to achieve a balance between the needs of transport services to the provision, transport services so the network capacity with public transportation road vehicle operating, as well as to ensure the quality of passenger transport services.

The Parties in transportation is the subject law as advocates the right and obligations in legal relations transportation. Wiwoho Soedjono Explained that in the sea transportation especially transporting goods, then need to be noticed the three elements which is: parties, sender the recipients of goods and the product itself. ${ }^{14}$

The transportation Agreement of goods relatedto the parties consist of :

a. The carrier, transportation service providers which are parties to provide transport services, goods and is entitled to payment acceptance rates as promised.

b. The owner of the transportation( transport service ), which had an obligation to pay the ( cost ) is set based on transport has been agreed upon and are entitled to receive the public transport services on goods he sent messengers throughout.

c. The recipients of goods ( users of ), which is equal to the sender, but whether the sender stuff too is as the party receives goods being transported in the destination

While in the event that the covenant of put in charge of carrying passengers, so the parties related to :

a. The carrier ( transport service providers ) which the conveyance of passengers to provide services to win the the cost of the reception of pay the fare ( fee ) in accordance transport that has been set.

b. The passengers ( transport users ) transport users the parties who receive services passengers and the obligation to pays rates on transportation cost.

\footnotetext{
${ }^{13}$ H.M.N Purwosutjipto,Pengertian Pokok Hukum...,p. 29

${ }^{14}$ Wiwoho Soejono, Hukum Pengangkutan Indonesia, Semarang,1999, p. 28
} 
The properties of transportation according to article 1601 -- article 1604 kuhperdata. Can be said that contracting according to the editors of article 1601 own, the contractor had to create something in particular (een bepaald werks tot stand to brengen) For the put out to contract (aanbesteder), So for a new object (new building, the , train tracks, and others) in fact that difficult to used in transportation, Absolutely not embodiment of new, but trying to carring goods as well as. That objects of charge entrusted him as a whole and complete, have not changed do not damaged or diminished until in the destination.

In code civil in france firmly diperbedakan between transportation and pemborongan agreement, that on the the transportation of goods and of persons arranged it alone in the civil code , in the article 1782-1786, and then this article have changed into w.v.k . In the Netherlands, article number 91 and so on ( it same with article number 91 in KUHD ), so it Not in pass in B.W in Netherland. ${ }^{15}$

The transportation of goods or people are a particular occupation that had to be met against parties who are have need of steadfast patience will that work by the provision of and glorious compensation of reward .The job include be paid out starting on waktu-waktu an ability which is required, to the inflation rate although when you they would not pay outstanding achievements in particular hauling a good land and a, who are in need put in charge of carrying will likely remain climbing into his waders and companies in transporting certain of which are known and of distinction

In general a legal relationship between the carrier for the user is the same high, the same low or both sides is "gecoordineerd". No counterpoise employer towards workers or counterpoise "gesubordineerd". No counterpoise employer towards workers or counterpoise gesubordineerd on a legal relationship between the user of transportation and carries. Because that is the nature of the agreement the transportation of a deal to do service ( services ) intervals (een overeenkomstot het verrichten van enkele diensten), In accordance with article 1601 kuhperdata .In subjects of this this of the nature for transporting the goods from one place to another place of the user desire for his business, and the process of conducted at regular intervals not like an employer that perpetually and an accomplice.

${ }^{15}$ Sutiono Usman Adji, dkk, Hukum Pengangkutan..., p. 7 
FITRAH Jurnal Kajian Ilmu-ilmu Keislaman

Vol. 05 No. 2 Desember 2019

\section{The Responsibility of the Transportation Law}

Entrepreneurs transportation are responsible for the safety goods, slowness the goods, damage and loss of goods that are transported thus position entrepreneurs transportation equal to transportation who does and article 91 kuhd saying: The carrier have to bear all the damage that occurs in other transport barang-barang once the goods that they had received to be transported, except broken caused by for a blemish on goods itself because the state of which force or by mistake or forgetfulness sender" ${ }^{16}$

The responsibility of law transportation in article 1236 kuhperdata state: Carriers must pay for the cost, and loss that deserves to be received if the carriers did not hand over or not treating only fitting to save the goods.

Article 438 paragraph 3 kuhd said : He was responsible for all of them, it has done and for all things that he used to carry out the transportation. In law the transportation there are three the principle of the responsibility responsibility for presumption , absolute and responsibility. ${ }^{17}$

1. Foult Liability

According to this principle, every carrier who made a mistake in performing transportation must be responsible pay all the taxes resulting from his fault. The party that suffered losses are required to prove it wrong pengangkut.beban of proof is on the injured party not to the pengangkut.prinsip is stipulated in article 1365 kuhperdata about an unlawful act as a rule umum.sedangkan special rules specified in undang-undang governing masing-masing types of transportation.

On motor transportation, such responsibility is stated in article 28 uulajr stated : The driver responsible for loss suffered by passengers or proprietor of goods that arises because of negligence or fault drivers. ${ }^{18}$

2. Presmption Liability

According to this principle, for transporting considered always responsible for any loss arising from the carrier that the convention, But if the

\footnotetext{
${ }^{16}$ Kitab Undang-Undang Hukum Perdata nomor 23 tahun 1847 tentang burgerlijk wetboek voor Indonesie, 1847

${ }_{17}$ Mr. E Suherman, Tanggung Jawab Pengangkutan Dalam Hukum Udara Indonesia, Bandung: N.V. Eresco I, 1962, p. 18

18 Undang-Undang Nomor 14 Tahun 1992, Tentang “lalu Lintas dan Angkutan Jalan Raya"
} 
carrier on able to prove that is innocent, then it released against any responsibility to complete the compensation payment. The definitions of "not responsible " is absence of negligence has tried to avoid the loss or the loss would not be avoided. The burden of proof is to the party for transporting, rather than on the party being disadvantaged. ${ }^{19}$ The party being disadvantaged adequately reflect the loss suffered in the transport of organized by the carrier.

Kuhd also adheres to the principle of the responsibility because of presumption. It can be read in article 468 paragraph 2 kuhd determines that the goods are transported it might not be given partially or wholly, or to the damage to , the transportation of responsible compensated to the shipper except if he is able to prove that it is not be submitted some or all of the or the damage to goods that is because event which can not be prevented or could not be avoided.

\section{Absolute Liability}

According to this principle, transport should be responsible for any harm arising in the transport of that convention without necessity verifiable where about the carrier. This principle mistake does not know the kind of mistake does not need to become a case later. Carries cannot be free from responsibility with any reason which have inflicted losses itu.prinsip below are the carrier is responsible for any harm arising in the operation because the incident any transportation.

Transport entrepreneurs responsible for loss suffered by passengers , and delivery of goods through negligence in implementing the public transport ( article 45 paragraph 1 ) UULAJR.

In the implementation of the transport, the safety of passengers or the goods are transported basically be in the responsibility of transport entrepreneurs .Thus, should when to transport entrepreneurs charged responsibility to any harm suffered by passengers or the sender goods that arises because of transportation did. With a such responsibility is carrying driven that always be careful; to anticipate responsibility in performing that might arise , article 46 uulajr determine, transport entrepreneurs must insure their responsibility .

${ }^{19}$ Mr. E Suherman, Tanggung Jawab Pengangkutan Dalam...., p. 23 
FITRAH Jurnal Kajian Ilmu-ilmu Keislaman

Vol. 05 No. 2 Desember 2019

The responsibility of the transportation entrepreneurs common against the owners of goods ( the sender ) is conducted from of goods received to be transported until this of goods to the sender or recipients ( article 46 paragraph 3 and 4 uulajr ). Amount of indemnification was recorded at a loss that is to be gained from a law constituent that should not be by the carrier on under the provisions of of the covenant that are his advantage because of the provisions of is aimed to force his way firing at ( dwingendrecht). Not including who have clearly suffered loss of the loss of volume there are :

a. Profits are expected to be obtained .

b. A deficiency caused by due to the road or bridge traversed along the way.

c. The cost for services is done.

The driver and vehicle owners responsible for car following the charge left in the way article 2 paragraph 24 ( uulajr), this means if a charge passengers or goods left on the path it has lost, so the driver or the vehicle owner is obliged to pay compensation together with joint responsibility. But in article 28 uulajr found, the driver in charge of loss by passengers, the owner, a third party that arises because of negligence or fault drivers in drive the vehicles. $^{20}$

\section{The Right and Obligation of the Parties}

In any agreement, of course there should be the ones who made a covenant that.Because without the agreement the parties, transportation if there is no peace treaty and the transport agreement not to be born .

Carrier is a person who fastens himself to organize transportation. While the sender is a person who fastens himself to pay money in return for services performed by the carrier in carrying out the transportation. ${ }^{21}$

A sender at an agreement the transportation of not only the individuals only, but can be also functions as a moving entity in the field of delivery of goods, where any body as is it is called with " ekspeditur " ekspeditur referred to with an official body or by whose business it is to make others to make good the transportation of goods by land,sea or the air. ${ }^{22}$

${ }^{20}$ Presiden RI, Undang-undang Republik Indonesia No. 22 Tahun 2009 tentang Lalu Lintas dan Angkutan Jalan, Jakarta, 2009,p. 34

${ }^{21}$ Presiden RI, Undang-undang Republik Indonesia No. 22 Tahun 2009..., p. 34

22 Presiden RI, Undang-undang Republik Indonesia No. 22 Tahun 2009..., p. 34 
The agreements between ekspeditur and a transmitter, called with the expedition while the ekspeditur on behalf of the sender with carrier called the agreement.

Then in a transportation is whether the act as the third party interested for it. For example someone who would move to another place, was necessary then they made a covenant with the transportation dabbling in the carriage to her do the transport where this. Intended Here the goods besides the acting as receiver, also acting as the sender.

While obligation the sender goods transport is pay money as big as what has diperjanjikan in a charge. And the payment of money transportation this could also be done by the recipient when have not yet been paid by the sender.This can be seen the recipient in a charge he received, because in a charge included whether money transportation have already been paid or not .If money transportation have not yet been paid so recipients are obliged to pay them as determined in a charge.

So on in this case the recipients of can be other interested parties in the agreement the transportation of after he said his will to receive goods and the recipient of them were obligated to pay the transportation of that goods.

In kuhd also set on rights and obligations and responsibilities of on for transporting or carrier.

The right for transporting or the transportation is in kuhd are :

1. Getting payment of this achievement done.

2. The carrier is entitled to a reimbursement of loss suffered because suratmenyurat necessary for the transportation was not submitted to it as it should.( article 478 verse 1 kuhd ).

3. Carrying entitled to receive reimbursement of loss of the day because shipments have provide information wrong or not complete about kind of when compared the goods, unless he know or should know will be the nature of and all that stuff the goods ( article verse 1 kuhd ).

In addition to the right the carrier or organizer, carrying also have an obligation and responsibilities arranged in kuhd .Where obligation and responsibility for transporting or the transportation is :

1. The carrier is obliged to keep the safety of goods carried from the moment he received until delivered up the goods ( article 468 verse 1 kuhd ). 
FITRAH Jurnal Kajian Ilmu-ilmu Keislaman

Vol. 05 No. 2 Desember 2019

2. Carriers must pay for the harm caused because the barang-barang wholly or some of it can be submitted and the goods damaged unless the burden may proves that no delivered up goods or the damage was caused by an evil that cannot be prevented or be avoided or is this handicapped is innate off the stuff or because the fault of the sender ( article 468 verse 2 kuhd ).

3. Carrying must be liable for the losses because delay the goods sent unless the burden may prove that this delay caused catastrophe not preventable or avoided ( article 447 kuhd ) .

Because the transportation of common agreement, occurring generally in orally and proven by ticket passengers, so these provisions ticket written on passengers .The conveyance of passengers held by several public transport company, good state-owned business entities and .With the provisions which are inscribed on ticket passengers who they published the varied but they will find all that in principle the contains the same rights and obligations.

\section{Compensation for passengers and cargo in public transportation service}

In the agreement on the goods transportation by the vehicle on main roads, in some cases does not work well as the parties and giving rise to the parties.

The emergence of such loss may be due to a situation or occurrence blocking. carrier to discharge its liabilitiesThe incident such as a things not to blame for ( overmatch or state of force or force majeure ).

In this case an obligation to bear that is one of the loss due to it is called " risk" .Loss also can occur due to a defect in respect of their goods own as well as a result of an error or me parties the sender .In addition loss can also inflicted as because they did not his perfect the implementation of the obligations of parties for transporting.

As was explained that an obligation is to hold the transportation of goods transport from the loading goods until in the destination safely and on time .If the goods transported survived, two issues will arise, namely their goods to the destination, but wholly or partially damaged goods and perhaps we do not get to the (destroyed ), possibly because burned, stolen and so on.

Another problem that often arise in the transport of which is about time until the goods at the destination was not in accordance with the previous treaty so that causes loss to the parties that have goods or the sender. 
The other things can be classify with destroy or fault goods generated outside the fault or negligence of the carrier in the agreement on the transportation of goods because of overmatch atau force majeure) a defect in the stuff can be seen by punishment before the transportation of goods transport, an error by omission sender itself .

The concept of overmatch ( force majeure ) there are two isms:

1. The objective ( de objective overmacth leer ) or absolute the debtors are in force majeure when not possible on that achievement by everyone or every person .

Content with what he taught scholars of mind is were loyal to a natural disaster on the great commission nor an accident what is neat about that, so as to be in all the books when they blood of any of you will not be able to memeuhi gained many achievement among them, also those that accumulate goods a ban of utter destruction or disappear beyond trade .Is considered to be a force majeure. For example, the vehicle that transports a landslide in the middle of the road.

2. The flow of subjective (de subkjective overmatch leer ) or relatively, namely force majeure is when a debtor may still carry out achievement, but practical with greater will be a very hard or sacrifice, so in the state of being thus that a creditor ca not prosecute the implementation of achievement. For example road and bridge followed accordingly, that it is hard to pass their goods are more expensive as the costs of their profits.

To passengers during the last transport, the driver given authorize by article 47 uulajr to down passenger and the goods are transported in stops nearest, when harm security and transportation safety.

This authority is accountable legally and propriety among the other things, there are $:^{23}$

1. Passengers who make the noise in a vehicle and have been warned first.

2. Goods are transported turns out dangerous for the safety of transport

3. Goods that can interfere with passengers because foul-smelling.

The carrier was lax in doing his job, so in accordance with the provisions of article 45 uulajr transport entrepreneurs responsible for loss suffered by

${ }^{23}$ Sinta Uli, Pengangkutan Suatu Tinjauan Hukum Multimoda Transport, Angkutan Laut, Angkutan Udara.Penerbit USU pres 2006, Medan, 2006. 
FITRAH Jurnal Kajian Ilmu-ilmu Keislaman

Vol. 05 No. 2 Desember 2019

passengers, a delivery guy, or a third party. Responsibility to began at the time of the real owner of goods received from the sender until goods was delivered to the recipients of the purposes to which has been agreed upon the persons concerned. But transportation enterprener is responsible for loss incurred when he can prove, there are :

1. The unexpected even first ( majeur force, article $1244 \mathrm{khu}$ perdata )

2. A defect in of itself .

3. Fault or omission sender o r negligence (article 91 KUHD).

The Following are all of thing to be observed sender passengers and goods in transportation and the responsibility of the carriers to do the transportation program both to the passengers and goods.

\section{CONCLUSION}

The transportation services in the transfer of goods or a from a place to another place in whose instrument, transport by land, nor the sea to transfer production goods to the consumer goods and trade. and vice versaNext in traksaksi is certainly happened bebarapa error and omission that is carried out by the carrier, it is some responsibility and accountability of them it was given a result of proof that the carrier, have done wrong the responsibility for, presumption carrying often deemed to be wrong but when can prove that errors not bersal from the transportation and the responsibility themselves but freed, the absolute and responsibilities without proven beforehand the carrier still wrong and must be responsible for the losses occurred. 


\section{REFERENCES}

\section{Buku.}

Abdul Kadir Muhammad, Hukum Pengangkutan Niaga, Penerbit PT Citra Aditya, Bandung, 1998.

Achmad Ichsan, Hukum Dagang Lembaga Surat-Surat Barharga, Pengangkutan, Pradnya Paramita,Jakarta, 1981.

Emmy Pangaribuan Simanjuntak,Hukum Dagang dan Surat-Surat Berharga Penerbit Seksi Hukum Dagang FH UGM, Yokyakarta, 1993.

Hasim Purba, Hukum Pengangkutan di Laut, penerbit Pustaka Bangsa Prees, Medan, 2005.

H.M.N Purwosutjipto,Pengertian Pokok Hukum Dagang Indonesia, Jilid 3,Djambatan, Jakarta, 1981.

Mr. R. Soekardono, Hukum Dagang Indonesia, Penerbit Soeroeng, Jakarta,1961.

Mr. E Suherman, “Tanggung Jawab Pengangkutan Dalam Hukum Udara Indonesia”, Bandung: N.V. Eresco I, 1962

Sinta Uli, "Pengangkutan Suatu Tinjauan Hukum Multimoda Transport, Angkutan Laut, Angkutan Udara."Penerbit USU pres 2006, Medan, 2006.

Sutiono UsmanAdji, dkk, "Hukum Pengangkutan Di Indonesia”,Penerbit Rineka Citra, Bandung, 1990.

Soekardono,Pengertian Pokok Hukum Dagang Indonesia, Penerbit soereong, Jakarta, 1981.

Wiwoho Soejono, "Hukum Pengangkutan Indonesia"Citra Aditya, Semarang,1999.

\section{Undang Undang}

R. Subekti, dkk, Kitab Undang-Undang hukum Dagang, PT Pradnya paramita,Jakarta,Cetakan 27,2002.

Presiden RI, Undang-undang Republik Indonesia No. 22 Tahun 2009 tentang Lalu Lintas dan Angkutan Jalan, Jakarta, 2009 
FITRAH Jurnal Kajian Ilmu-ilmu Keislaman

Vol. 05 No. 2 Desember 2019

Undang-Undang Nomor 14 Tahun 1992, Tentang “Lalu Lintas dan Angkutan Jalan Raya"

Kitab Undang-Undang Hukum Perdata nomor 23 tahun 1847 tentang burgerlijk wetboek voor Indonesie, 1847 